\title{
Nursing diagnoses for patients in the postoperative period of cardiac surgery
}

\author{
Diagnósticos de enfermagem em pacientes no pós-operatório de cirurgia cardíaca \\ Diagnósticos de enfermería en pacientes en el postoperatorio de cirugía cardíaca
}

\begin{abstract}
Carla Portolan Ribeiro ${ }^{1}$, Caroline de Oliveira Silveira ${ }^{2}$, Eliane Raquel Rieth Benetti ${ }^{3}$, Joseila Sonego Gomes ${ }^{4}$, Eniva
\end{abstract} Miladi Fernandes Stumm ${ }^{4}$

Objective: to identify nursing diagnoses of patients in mediate postoperative period of cardiac surgery. Methods: descriptive, cross-sectional design with 26 patients in mediate postoperative period of cardiac surgery, in an intensive care unit. Data were collected through a form of socio-demographic/clinic characterization and nursing diagnoses. Results: one identified 15 risk nursing diagnoses and 34 real diagnoses, and the most common were related to the domain safety and protection. Conclusion: the identification of nursing diagnoses in patients after cardiac surgery allows one to direct nursing care and support appropriate interventions to individual needs, because patients in these conditions require immediate and accurate interventions.

Descriptors: Thoracic Surgery; Nursing Diagnosis; Perioperative Care; Nursing.

Objetivo: identificar os diagnósticos de enfermagem de pacientes em pós-operatório mediato de cirurgia cardíaca. Métodos: desenho descritivo, transversal com 26 pacientes em pós-operatório mediato de cirurgia cardíaca, internados em unidade de terapia intensiva. Os dados foram coletados por meio de Formulário de Caracterização Sociodemográfica/Clínica e Diagnósticos de Enfermagem. Resultados: foram identificados 15 diagnósticos de enfermagem de risco e 34 diagnósticos reais, sendo os mais frequentes relacionados ao domínio segurança e proteção. Conclusão: a identificação de diagnósticos de enfermagem em pacientes no pós-operatório de cirurgia cardíaca permite direcionar a assistência de enfermagem e subsidiar intervenções adequadas às necessidades individuais, pois pacientes nessas condições requerem intervenções imediatas e precisas.

Descritores: Cirurgia Torácica; Diagnóstico de Enfermagem; Assistência Perioperatória; Enfermagem.

Objetivo: identificar los diagnósticos de enfermería de pacientes en postoperatorio de cirugía cardiaca. Métodos: diseño descriptivo, transversal, con 26 pacientes en postoperatorio de cirugía cardiaca, en la unidad de cuidados intensivos. Datos recolectados a través de Formulario de Caracterización Sociodemográfica/Clínica y Diagnósticos de Enfermería. Resultados: se identificaron 15 diagnósticos de enfermería de riesgo y 34 diagnósticos reales, siendo los más frecuentes relacionados con el dominio seguridad y protección. Conclusión: la identificación de diagnósticos de enfermería en pacientes en postoperatorio de cirugía cardíaca permite direccionar la atención de enfermería y apoyar intervenciones adecuadas a las necesidades individuales, ya que pacientes en estas condiciones requieren intervenciones inmediatas y precisas.

Descriptores: Cirugía Torácica; Diagnóstico de Enfermería; Atención Perioperativa; Enfermería.

\footnotetext{
${ }^{1}$ Hospital Tacchini. Bento Gonçalves, RS, Brazil.

${ }^{2}$ Hospital Unimed Noroeste. Ijuí, RS Brazil.

${ }^{3}$ Hospital Universitário de Santa Maria. Santa Maria, RS, Brazil.

${ }^{4}$ Universidade Regional do Noroeste do Estado do Rio Grande do Sul. Ijuí, RS, Brazil.

Corresponding author: Eniva Miladi Fernandes Stumm

Rua 20 de setembro, 902 Centro, CEP: 98700-000 - Ijuí, RS, Brazil. E-mail: eniva@unijui.edu.br
} 


\section{Introduction}

Cardiovascular diseases have been present in recent decades in a significant proportion among the causes of morbidity and mortality, both in developed and in developing countries. In Brazil these diseases are the leading causes of death in men and women, accounting for about $20 \%$ of all deaths in people over 30 years old and also for high rates of hospitalization and hospital expenses ${ }^{(1)}$.

In Brazil recent trends indicate that the mortality of some cardiovascular diseases is decreasing, suggesting that the confrontation is going in the right direction and, consequently, the number of patients with cardiovascular diseases who require care tends to increase ${ }^{(2)}$. Therefore, there is a need to organize, qualify and expand services, including nursing care.

For having a chronicity character, the treatment of these diseases can be clinical or surgical and it aims to restore the heart's functional capacity in order to lessen the symptoms and allow individuals to return to their normal activities ${ }^{(3)}$. In this context, although the clinical treatment of heart diseases has progressed and minimally invasive procedures are rapidly expanding, the heart surgery is the intervention chosen in many cases.

Cardiac surgery is performed when the probability of surviving is higher with surgical treatment than with medical therapy. This is a complex procedure that has organic repercussions, modifying in various ways the physiological mechanisms, which implies the need of intensive care in order to establish recovery ${ }^{(4)}$.

Thus, the technological advance of the treatment for cardiovascular diseases, as well as the complexity of care required by patients undergoing cardiac surgery, whose health condition is constantly changing, demand immediate and accurate nursing interventions that require scientifically based planning ${ }^{(5)}$. Nursing care is critical to the recovery of patients who undergo surgery and due to that context nursing has enhanced its knowledge and implemented new alternatives of service, through its own work methodology, based on the scientific method, defined as the systematization of nursing care.

The systematization has been implemented in healthcare practices and it provides greater safety for patients, improves their quality of care and the autonomy to nursing professionals ${ }^{(6)}$, by organizing work according to its method, staff and instruments and by facilitating the operationalization of the nursing process $^{(7)}$. This methodological toolguidesprofessional care and the documentation of professional practices, increasing the profession's visibility and recognition. For this, nursing process is organized into five steps interrelated and interdependent, namely: Nursing History, Nursing Diagnosis, Planning, Implementation and Nursing Evaluation. Among the steps, nursing diagnosis is recognized as a guide for planning and implementation of interventions, because it represents the basis for the selection of actions or interventions which are aimed at achieving the expected results ${ }^{(7)}$.

Nursing diagnoses are clinical trials about the responses of individuals to real or potential health problems, which subsidize nursing interventions to achieve outcomes for which nurses are responsible ${ }^{(8)}$. This trial provides criteria for the evaluation of assistance, and it also directs care, facilitates research and teaching, encourages patients to participate in their treatment and in their therapeutic plan and contributes to the expansion of nursing knowledge ${ }^{(6)}$.

In this context, given the complexity of care required by individuals in the postoperative period of cardiac surgery in intensive care, whose health conditions are constantly changing and require immediate and accurate nursing interventions, it was decided to identify the nursing diagnoses in mediate postoperative period of cardiac surgery. It is considered that the identification of these diagnoses 
may qualify nursing care, as well as support the development of an individualized care plan, based on interventions that aim at results, provide patients with safety and the nursing staff with autonomy.

The recognition of nursing diagnoses, besides facilitating the association between clinical data and nursing care, can direct the creation of specific protocols for nursing care, and can serve as a vehicle of change and transformation of clinical practice ${ }^{(9)}$. Still, one highlights the small number of studies related to nursing diagnoses, developed with patients in the postoperative period of cardiac surgery. Thus, this study aims to broaden the scope of literature about the practical application of nursing diagnoses.

In this context, this study aimed to identify nursing diagnoses of patients in mediate postoperative period of cardiac surgery.

\section{Method}

This is a descriptive study, with cross-sectional design and quantitative approach, performed in an intensive cardiac care unit of a general hospital, size IV, from the city of Ijuí, RS, Brazil.

The sample was chosen by consecutive convenience, which aims to investigate all the accessible people who met the inclusion criteria of the study, in a given time ${ }^{(10)}$. Twenty-six patients who underwent cardiac surgery in mediate postoperative period participated in the study and the ones who met the inclusion criteria, namely: being 18 years old and being admitted to the cardiac intensive care unit, in the mediate postoperative period ( 24 hours to seven days) of cardiac surgery. One excluded patients who had severe complications in the immediate postoperative period ( $<24$ hours), such as bleeding requiring reoperation and neurological complications related to cardiopulmonary bypass.

Data collection was conducted from April 4 to May 28 2013, by the researchers, after training and pilot testing through a research protocol, consisting of a patient's socio-demographic and clinical characterization form and of a nursing diagnosis form, which were developed and validated by the researchers based on the domains of diagnoses of Taxonomy II ${ }^{(9)}$ from NANDA and it allowed the identification and collection of diagnostic titles, defining characteristics and related factors of nursing diagnoses. Having the free and informed consent form signed by patients or their family members, one conducted a thorough evaluation of patients, in order to identify the basic needs affected through clinical reasoning and the nursing diagnoses through diagnostic trial.

After collection, the data were organized and stored in a spreadsheet, in the program Excel for Windows (Office, 2007), and subsequently analyzed electronically. Descriptive statistics was used to analyze the qualitative and quantitative variables, expressed in simple and relative frequencies (\%).

The ethical principles of resolution 196/96 were respected and the project was approved by the research ethics committee, embodied opinion $\mathrm{n}^{\mathrm{o}}$ 215,659 .

\section{Results}

Among the 26 patients, $84.62 \%$ were attended by the Unified Health System, while $15.3 \%$ by other health insurances. As to their profession and/or occupation, $30.7 \%$ were farmers; $11.5 \%$ salespeople and the other percentages had different occupations. As for religion, most of them (65.3\%) reported being catholic.

As shown in Table 1, out of the patients who underwent cardiac surgery, a higher proportion (76.9\%) was composed of males, between 51 and 70 years old (61.4\%), married (84.6\%), with two or more children and $65.3 \%$ reported schooling equivalent to elementary school. 
Table 1 - Socio-demographic characteristics of patients who underwent cardiac surgery

\begin{tabular}{|c|c|}
\hline Sociodemographic characteristics & n (\%) \\
\hline \multicolumn{2}{|l|}{ Gender } \\
\hline Male & 20 (76.9) \\
\hline Female & $6(23.1)$ \\
\hline \multicolumn{2}{|l|}{ Age (years) } \\
\hline $41-50$ & $3(11.5)$ \\
\hline $51-60$ & $10(38.5)$ \\
\hline$>61$ & $13(50.0)$ \\
\hline \multicolumn{2}{|l|}{ Marital status } \\
\hline Married/with a life partner & $22(84.6)$ \\
\hline Single & $3(11.5)$ \\
\hline Separated/Divorced & $1(3.9)$ \\
\hline \multicolumn{2}{|l|}{ Number of children } \\
\hline None & $3(11.5)$ \\
\hline 1 & $3(11.5)$ \\
\hline 2 & $8(30.8)$ \\
\hline$\geq 3$ & $12(46.2)$ \\
\hline \multicolumn{2}{|l|}{ Educational level } \\
\hline Unschooled & $3(11.5)$ \\
\hline Elementary School & $17(65.4)$ \\
\hline High school & $4(15.4)$ \\
\hline College degree/Graduate School & $2(7.7)$ \\
\hline Total & $26(100.0)$ \\
\hline
\end{tabular}

Regarding cardiopulmonary bypass $96.1 \%$ of the patients used it, for $68 \%$ of patients the time of cardiopulmonary bypass was from 61 to 120 minutes. Regarding the postoperative period, at the time of data collection, $76.9 \%$ of patients had undergone surgery in the period between 24 and 48 hours.
Table 2 - Clinical characteristics of patients who underwent cardiac surgery

\begin{tabular}{|c|c|}
\hline Clinical characteristics & n (\%) \\
\hline \multicolumn{2}{|l|}{ Diagnosis before cardiac surgery } \\
\hline Coronary arterial diseases & $7(26.8)$ \\
\hline Aortic regurgitation & $6(23.1)$ \\
\hline Acute myocardial infarction & $6(23.1)$ \\
\hline Angina & $5(19.2)$ \\
\hline Endocarditis & $1(3.9)$ \\
\hline Non-congestive Heart Failure & $1(3.9)$ \\
\hline \multicolumn{2}{|l|}{ Surgical procedure conducted } \\
\hline Myocardial revascularization & $18(69.1)$ \\
\hline Aortic valve exchange & $5(19.2)$ \\
\hline Implantation of aortic valve prosthesis & $1(3.9)$ \\
\hline Mitral valve exchange & $1(3.9)$ \\
\hline Myocardial revascularization + Valve exchange & $1(3.9)$ \\
\hline \multicolumn{2}{|l|}{ Cardiopulmonary bypass } \\
\hline Yes & 25 (96.1) \\
\hline No & $1(3.9)$ \\
\hline \multicolumn{2}{|l|}{ Cardiopulmonary bypass time (minutes) } \\
\hline$<60$ & $4(15.4)$ \\
\hline $60-120$ & $17(65.4)$ \\
\hline$\geq 121$ & $4(15.4)$ \\
\hline \multicolumn{2}{|l|}{ Comorbidities } \\
\hline Diabetes mellitus & $12(46.2)$ \\
\hline Arterial hypertension & $19(73.1)$ \\
\hline Cardiac diseases & $11(42.3)$ \\
\hline Dyslipidemias & $5(19.2)$ \\
\hline \multicolumn{2}{|l|}{ Risk factors } \\
\hline Sedentary lifestyle & $9(34.6)$ \\
\hline Obesity & $4(15.4)$ \\
\hline Smoking & $11(42.3)$ \\
\hline Alcoholism & $3(11.5)$ \\
\hline Family Background & $19(73.1)$ \\
\hline
\end{tabular}

Table 3 shows the risk nursing diagnoses, among which one verifies that those identified in all the patients are included in the domains of safety/ protection, activity/rest and nutrition. 
Table 3 - Risk nursing diagnoses identified in patients in the mediate postoperative period of cardiac surgery

\begin{tabular}{lllc}
\hline Nursing diagnoses & Domain & n (\%) & CI (95\%) \\
\hline Risk for ineffective renal perfusion & Activity / Rest & $26(100.0)$ & - \\
Risk for decreased cardiac tissue perfusion & Activity / Rest & $26(100.0)$ & - \\
Risk for bleeding & Safety / Protection & $26(100.0)$ & - \\
Risk for infection & Safety / Protection & $26(100.0)$ & - \\
Impaired skin integrity & Safety / Protection & $26(100.0)$ & - \\
Risk for perioperative positioning injury & Safety / Protection & $26(100.0)$ & - \\
Risk for falls & Safety / Protection & $26(100.0)$ & - \\
Risk for vascular trauma & Safety / Protection & $26(100.0)$ & - \\
Risk for electrolyte imbalance & Nutrition & $26(100.0)$ & - \\
Constipation & Elimination and exchange & $25(96.1)$ & 88.8 to 103.5 \\
Risk for unstable blood glucose level & Nutrition & $20(76.9)$ & 60.7 to 93.1 \\
Risk for acute confusion & Perception / Cognition & $10(38.4)$ & 19.8 to 57.2 \\
Risk for shock & Safety / Protection & $6(23.0)$ & 6.9 to 39.3 \\
Risk for spiritual distress & Life Principles & $3(11.5)$ & 0 to 23.8 \\
Risk for impaired religiosity & Life Principles & $1(3.8)$ & 0 to 11.2 \\
\hline
\end{tabular}

*When $\mathrm{n}=100 \%, \mathrm{CI}=$ confidence interval $(-)$

Table 4 shows the real nursing diagnoses, wellness and health promotion, which shows that the impaired physical mobility was identified in all pati- ents $(100 \%)$ and impaired bed mobility in $76.92 \%$, diagnoses within the domain activity/rest.

Table 4 - Real nursing diagnoses of wellness and health promotion identified in patients in the postoperative period of cardiac surgery

\begin{tabular}{|c|c|c|c|}
\hline Nursing Diagnoses & Domain & n (\%) & CI (95\%) \\
\hline Impaired physical mobility & Activity / Rest & $26(100.0)$ & - \\
\hline Impaired bed mobility & Activity / Rest & $20(76.9)$ & 60.7 to 93.1 \\
\hline Readiness for enhanced family processes & Role Relationships & $20(76.9)$ & 60.7 to 93.1 \\
\hline Readiness for enhanced self-control & Self-perception & $18(69.2)$ & 51.5 to 87.0 \\
\hline Impaired comfort & Comfort & $16(61.5)$ & 42.8 to 80.2 \\
\hline Dysfunctional gastrointestinal motility & Elimination and Exchange & $15(57.7)$ & 38.7 to 76.7 \\
\hline Impaired walking & Activity / Rest & $15(57.7)$ & 38.7 to 76.7 \\
\hline Acute pain & Comfort & $14(53.8)$ & 34.7 to 73.0 \\
\hline Delayed surgical recovery & Safety / Protection & $11(42.3)$ & 23.3 to 61.3 \\
\hline Disturbed sleep pattern & Activity / Rest & $10(38.5)$ & 20.1 to 57.6 \\
\hline Fear & Coping / Stress tolerance & $10(38.5)$ & 20.1 to 57.6 \\
\hline Fatigue & Activity / Rest & $9(34.6)$ & 16.3 to 52.9 \\
\hline Ineffective breathing pattern & Activity / Rest & $9(34.6)$ & 16.3 to 52.9 \\
\hline Insomnia & Activity / Rest & $9(34.6)$ & 16.3 to 52.9 \\
\hline Impaired spontaneous ventilation & Activity / Rest & 7 (26.9) & 9.9 to 44.0 \\
\hline Deficient diversional activity & Health Promotion & $6(23.1)$ & 6.9 to 39.3 \\
\hline Impaired verbal communication & Perception / Cognition & $6(23.1)$ & 6.9 to 39.3 \\
\hline Anxiety & Coping / Stress tolerance & $5(19.2)$ & 4.134 .4 \\
\hline Ineffective self health management & Health Promotion & $5(19.2)$ & 4.134 .4 \\
\hline Ineffective family therapeutic regimen management & Health Promotion & $4(15.4)$ & 1.5 to 29.2 \\
\hline Risk for ineffective peripheral tissue perfusion & Activity / Rest & $4(15.4)$ & 1.5 to 29.2 \\
\hline Relocation stress syndrome & Coping / Stress tolerance & $4(15.4)$ & 1.5 to 29.2 \\
\hline Hyperthermia & Safety / Protection & $3(11.5)$ & 0 to 23.8 \\
\hline Ineffective thermoregulation & Safety / Protection & $3(11.5)$ & 0 to 23.8 \\
\hline Deficient fluid volume & Nutrition & $3(11.5)$ & 0 to 23.8 \\
\hline Constipation & Elimination and Exchange & $3(11.5)$ & 0 to 23.8 \\
\hline Impaired gas exchange & Elimination and Exchange & $2(7.7)$ & 0 to 17.9 \\
\hline Decreased cardiac output & Activity / Rest & $2(7.7)$ & 0 to 17.9 \\
\hline Self-neglect & Activity / Rest & $2(7.7)$ & 0 to 17.9 \\
\hline Nausea & Comfort & $2(7.7)$ & 0 to 17.9 \\
\hline Impaired swallowing & Nutrition & $1(3.9)$ & 0 to 11.2 \\
\hline Imbalanced nutrition: less than body requirements & Nutrition & $1(3.9)$ & 0 to 11.2 \\
\hline Impaired social interaction & Role Relationships & $1(3.9)$ & 0 to 11.2 \\
\hline Impaired oral mucous membrane & Safety / Protection & $1(3.9)$ & 0 to 11.2 \\
\hline
\end{tabular}




\section{Discussion}

The prevalence of men who underwent cardiac surgery has been a result shown in other studies in the postoperative period of this procedure ${ }^{(11-14)}$. Regarding the age of the study subjects, it is known that age is a factor that influences directly in the postoperative recovery because with increased age there are more complications and a reduced recovery capacity ${ }^{(12)}$. As seen in this study, the prevalence of elderly patients is evident in hospitals, despite the considerable increase of diseases in other age groups.

It was found that $84.6 \%$ of the study subjects are married, similar to results observed in a crosssectional study with patients in the postoperative period of cardiac surgery in Fortaleza/Ceará(13). Regarding educational level, $65.4 \%$ had completed elementary school, data that differs from a study patients with patients in the postoperative period of myocardial revascularization, in which $45.5 \%$ had not completed elementary school and 31, 8\% could not read or write ${ }^{(13)}$. In relation to this variable, one infers that a better education enables better living conditions and consequently reflects positively on individuals' health status.

As for the diagnosis of heart diseases before surgery, $26.9 \%$ of the patients had coronary artery diseases, $23.1 \%$ had aortic insufficiency and also $23.1 \%$ acute myocardial infarction, $19.2 \%$ angina and $3.9 \%$ endocarditis and non-congestive heart failure. In a study conducted in Bauru/SP with patients in the postoperative period of cardiac surgery, the diseases diagnosed were acute myocardial infarction (60\%), heart failure $(15 \%)$, problems of malformation and aortic stenosis $(15 \%)$ and congestive heart failure $(10 \%)^{(12)}$.

Among the surgical procedures performed by the subjects of this study, $69.2 \%$ underwent myocardial revascularization, $19.2 \%$ aortic valve replacement, $3.9 \%$ aortic valve prosthesis implantation, 3.9\% myocardial revascularization + aortic valve replacement. Similar results were found in a study conducted in São Paulo with patients in the perioperative period of cardiac surgery, in which $70 \%$ of the study subjects underwent myocardial revascularization, $12 \%$ mitral valve replacement, $6 \%$ mitral and tricuspid valve repair, and $6 \%$ mitral and tricuspid valve replacement and $6 \%$ mitral valve replacement and tricuspid valve repair ${ }^{(3)}$. These results show that myocardial revascularization is the most frequent among the cardiac surgeries, despite the evolution of minimally invasive procedures such as percutaneous transluminal coronary angioplasty.

Regarding the use of cardiopulmonary bypass $96.1 \%$ were submitted to it, and $65.4 \%$ stayed from 61 to 120 minutes (average time of 82 minutes). Similarly, $86.2 \%$ of patients who underwent myocardial revascularization in a medium-sized hospital in the countryside of Goiás remained in cardiopulmonary bypass for an average time of 1.29 hours $^{(15)}$. It is considered that the time of cardiopulmonary bypass is one of the factors contributing to the occurrence of some complications during and after surgery, as hypovolemic shock, respiratory/metabolic disorders, which require quick corrections ${ }^{(16)}$.

As for the comorbidities presented, one highlights systemic hypertension (73.9\%), diabetes mellitus (46.2\%), heart diseases (42.3\%) and dyslipidemias (19.2\%). These comorbidities were also found with similar frequency in a study that found out that $78.9 \%$ of the subjects had systemic hypertension, $57.9 \%$ diabetes mellitus and $31.6 \%$ dyslipidemia ${ }^{(14)}$. In another study, the frequent comorbidities were systemic hypertension (50\%), diabetes mellitus (25\%) and systemic hypertension + diabetes mellitus (10\%) (12). These numbers reinforce the need for actions of health professionals in different attention levels, both for early diagnosis and for access to treatment of these pathologies.

Regarding risk factors one identified family history (73.1\%), smoking (42.3\%), physical inactivity (34\%), obesity $(15.4 \%)$ and alcohol consumption $(11.5 \%)$. In a study, with the same object of study, $57.9 \%$ of the subjects were smokers, $47.4 \%$ sedentary, 
$26.4 \%$ obese and $15.8 \%$ alcoholics, results similar to those found in this study ${ }^{(12)}$. Knowledge about socio-demographic and clinical variables of patients who underwent cardiac surgery is important for the planning of nursing care, as each group establishes individual characteristics that should be valued, and some signs and symptoms are more common in one sex or the other, as the perception of pain and psychosomatic disorders, such as anxiety and fear.

Among the risk diagnoses identified, one highlights that the risk of electrolyte imbalance, ineffective renal perfusion, decreased heart tissue perfusion, bleeding, infection, impaired skin integrity, perioperative positioning injury, falls and vascular trauma were identified in $100 \%$ of patients who underwent cardiac surgery. Also, in a study with patients in the mediate postoperative period of cardiac surgery, the risk for infection was identified in $100 \%$ of the patients surveyed ${ }^{(13)}$.

All the patients who underwent cardiac surgery are at risk of infection and bleeding, due to invasive procedures such as bladder catheterization, central venous access, chest and mediastinal drains, arterial access for mean arterial pressure, besides the destruction of tissues and primary defenses. Besides these, blood transfusion is associated with infection and morbidity, because there is blood loss and blood transfusion $^{(17)}$.

In the identification of risk diagnoses, one also highlighted the risk for constipation (96.1\%), for unstable blood glucose (76.9\%) and for acute confusion (38.5\%), a result corroborated by studies that identified the risk for constipation in $100 \%{ }^{(15)}$, and $78.09 \%$ of the patients ${ }^{(13)}$. It is understood that this diagnosis is associated with functional risk factors, such as insufficient physical activity, and with the physiological, such as changes in eating patterns and impaired gastrointestinal motility.

One identified in $76.9 \%$ of the patients the risk for unstable blood glucose, defined as the potential variation in the levels of glucose/blood sugar in relation to normal parameters ${ }^{(18)}$. In this aspect, it is emphasized that patients with a history of diabetes are at increased risk for unstable blood sugar, because of the long fasting period to which they are subjected, and in some cases, it is necessary the use of hypoglycemic medication to normalize their serum glucose level ${ }^{(18)}$. In the meantime, it is important to know patients' risk factors and comorbidities in order to predict probable complications.

Among the risk nursing diagnoses identified, most are classified in the domain safety and protection. This result shows that the identification and care of the affected basic human needs is important, with the objective of full nursing care to the patient.

In a study that identified the nursing diagnoses present in patients after cardiac surgery, in Fortaleza/ $\mathrm{CE}$, the most common diagnoses in the immediate postoperative period were impaired skin integrity (100\%), impaired physical mobility (100\%), risk for infection (100\%), for aspiration (100\%), for shock (100\%), for deficient fluid volume (100\%), ineffective airway clearance (63.1\%), risk for imbalanced body temperature $(52.6 \%)$ and acute pain $(26.3 \%)^{(13)}$. In the present study, the diagnosis impaired physical mobility was detected in $100 \%$ of the patients, while impaired bed mobility in $76.9 \%$. This diagnosis is defined as any limitation to move independently, changing position in bed ${ }^{(11)}$, which can be related to the restriction resulting from the surgical procedure, due to drainage that restricts body movements and due to pain while moving.

In the same proportion, $76.9 \%$ had readiness for enhanced family processes, a diagnosis that deserves attention in the moment of planning the interventions and nursing outcomes for patients and their families. It is up to nurses to identify the needs of patients and their families, through systematic actions of the nursing process in order to attend them in their specificities and to promote comfort in recovery after hospital discharge.

One of the real diagnoses that patients in the postoperative period of cardiac surgery had, and that deserves attention was acute pain (53.8\%). Pain is 
an unpleasant sensory and emotional experience of sudden or slow onset, with mild to severe intensity ${ }^{(14)}$. Its presence can predict complications, which should be dealt with quickly and accurately ${ }^{(19)}$. Therefore, any reports of pain from patients should be investigated and evaluated systematically, both the intensity and description of the reported complaint of pain.

It is noteworthy that the main diagnoses were shown by potential and real physiological changes in the postoperative period, which confirms that the nursing staff should monitor the hemodynamic changes and conditions that promote patients' stability. Thus, nursing care is established in accordance with the patients' needs, in order to maintain the hemodynamic balance and their vital functions and they may vary according to the stage of postoperative period, if immediate, mediate or late. In addition to the physical aspects, there is an emphasis on the psycho-emotional needs that can be highlighted and negatively influence patients' recovery and therefore require intervention.

In this perspective, nurses must make efforts in the systematization of nursing care based on the nursing process, because they will be able to provide holistic, individualized and humanized care.

\section{Conclusions}

This study allowed the identification of demographic/clinical characteristics and nursing diagnoses for patients in the mediate postoperative period of cardiac surgery, and the most prevalent were those related to the domain safety and protection. As a cardiac surgery is an invasive procedure, with highrisk, patients who undergo it need qualified assistance during the perioperative period because the form of approach will contribute to the achievement of satisfactory results in their recovery.

Accordingly, the incorporation of nursing diagnoses provides the development of a care plan, covering the most affected biological, physical and emotional needs, so care becomes individualized and systematic. It is worth mentioning the importance of the nursing process as the working method that nurses use in the care of patients who underwent cardiac surgery, in order to favor their return to their family and work context as soon as possible.

This study, even with limitations related to the type of study and the number of subjects, reveals that the knowledge about the health problems of a group of patients with common characteristics, can direct nursing care as well as provide support for the preparation of a care plan, the implementation of interventions, training and qualification of the nursing team. Therefore, it is essential to develop research related to the identification of nursing diagnoses, aiming to direct them to the analysis of problems of patients who require specific nursing actions. Thus, besides contributing to the increase of research on the subject, it can contribute to the development of nursing as a science.

\section{Collaborations}

Ribeiro CP and Benetti ERR contributed to the construction of the project, in conducting the study, data analysis and writing. Silveira CO, Gomes JS and Stumm EMF contributed to the data analysis and writing.

\section{References}

1. Mansur AP, Favarato D. Mortality due to cardiovascular diseases in Brazil and in the metropolitan region of São Paulo: a 2011 update. Arq Bras Cardiol. 2012; 99(2):755-61.

2. Duncan BB, Chor D, Aquino EML, Bensenor IM, Mill JG, Schmidt MI, et al. Doenças Crônicas Não Transmissíveis no Brasil: prioridade para enfrentamento e investigação. Rev Saúde Pública. 2012; 46(Supl):126-34.

3. Galdeano LE, Rossi LA, Santos CB, Dantas RA. Diagnósticos de enfermagem no perioperatório de cirurgia cardíaca. Rev Esc Enferm USP. 2006; 40(1):26-33. 
4. Soares GMT, Ferreira DCS, Gonçalves MPC, Alves TGS, David FL, Henriques KMC, et al. Prevalência das Principais Complicações Pós-Operatórias em Cirurgias Cardíacas. Rev Bras Cardiol. 2011; 24(3):139-46.

5. Lira ALBC, Araújo WM, Souza NTC, Frazão CMFQ, Medeiros ABA. Mapeamento dos cuidados de enfermagem para pacientes em pós-operatório de cirurgia cardíaca. Rev Rene. 2012; 13(5):1171-81.

6. Tannure MC, Pinheiro AM. SAE - Sistematização da assistência de enfermagem - guia prático. São Paulo: Guanabara Koogan; 2011.

7. Conselho Federal de Enfermagem. Resolução COFEN n 358 de 15 de outubro de 2009. Dispõe sobre a Sistematização da Assistência de Enfermagem (SAE) nas Instituições de Saúde Brasileiras. Rio de Janeiro: Conselho Federal de Enfermagem; 2009.

8. NANDA Internacional. Diagnósticos de enfermagem: definições e classificação 2012-2014. Porto Alegre: Artmed; 2013.

9. Nunciaroni AT, Gallani MCBJ, Rodrigues RCM, Agondi RF, Castro LT. Caracterização dos diagnósticos de enfermagem de pacientes internados em uma unidade de cardiologia. Rev Gaúcha Enferm. 2012; 33(1):32-41.

10. Hulley SB, Newman TB, Cummings SR. Escolhendo os sujeitos do estudo: especificação, amostragem e recrutamento. In: Hulley SB, Cummings SR, Browner WS, Grady DG, Newman TB. Delineando a pesquisa clínica: uma abordagem epidemiológica. Porto Alegre: Artmed; 2008. p. 43-54.

11. Pivoto FL, Lunardi Filho WD, Santos SSC, Almeida MA, Silveira RS. Nursing diagnoses in patients in the postoperative period of cardiac surgery. Acta Paul Enferm. 2010; 23(5):665-70.
12. Cruz APO, Lopes R. Diagnóstico de enfermagem no pós-operatório de cirurgias cardíacas. Salusvita. 2010; 29(3):293-312.

13. Oliveira SKP, Lima FET, Leitão IMTA, Mendonça LBA, Meneses LST, Oliveira RM. Diagnósticos de enfermagem presentes em pacientes adultos no pós-operatório de cirurgia cardíaca. Rev Enferm UFPI. 2012; 1(2):95-100.

14. Rocha LA, Maia TF, Silva LF. Diagnósticos de enfermagem em pacientes submetidos à cirurgia cardíaca. Rev Bras Enferm. 2006; 59(3):321-6.

15. Rodrigues FCS, Totó YR, Stival MM, Lima LR. Hemotransfusão no pós-operatório de cirurgia cardíaca. Rev Enferm Integrada . 2012; 5(2):9961007.

16. Dienstmann C, Caregnato RCA. Circulação extracorpórea em cirurgia cardíaca: um campo de trabalho para o enfermeiro. Rev SOBECC. 2013; 18(1):35-43.

17. Issa $M$, Avezum A, Dantas DC, Almeida AFS, Souza LCB; Sousa AGMR. Risk factors for pre, intra, and postoperative hospital mortality in patients undergoing aortic surgery. Rev Bras Cir Cardiovasc. 2013; 28(1):10-21.

18. Souza TM, Carvalho R, Paldino CM. Diagnósticos, prognósticos e intervenções de em enfermagem na sala de recuperação pós-anestésica. Rev SOBECC. 2012; 17(4):33-47.

19. Souza KN, Stival MM, Lima LR. Avaliação da dor em pacientes submetidos à angioplastia coronária transluminal Percutânea. Universitas Ciênc Saúde. 2012; 10(1):15-22. 